Anuário de Literatura

Volume 15

Número 02

\title{
A EXPERIÊNCIA AMBÍGUA DO GOZO E DO CORPO EM A CÉU ABERTO
}

Marcio Markendof Doutor em Literatura

Professor dos Cursos de Letras e Cinema -UFSC 


\section{THE AMBIGUOUS EXPERIENCE OF THE JOUISSANCE AND OF THE BODY IN THE NOVEL A CÉU ABERTO}

RESUMO: Ao tomar como objeto de estudo o livro A céu aberto, de João Gilberto Noll, este artigo pretende discutir o tema da ambiguidade na literatura contemporânea. A análise está centralizada na avaliação de um corpo doppelgänger, indeterminado em relação à sexualidade, ao gozo e ao gênero.

PALAVRAS-CHAVE: doppelgänger; corpo; gozo; gênero.

Abstract: Taking as its object of study the book $A$ céu aberto, written by João Gilberto Noll, this paper discusses the theme of ambiguity in contemporary literature. The analysis is focused on the evaluation of a doppelgänger body, indeterminate in relation to sexuality, gender and jouissance.

KEY-WORDS: doppelgänger; body; jouissance; gender. 
Uma das tendências da narrativa contemporânea brasileira, a exemplo de outras literaturas produzidas fora do território, é a de apresentar como traço distintivo o encaminhamento da matéria narrativa para um espaço de tensões, ambiguidades e despersonalização. Semelhante qualidade pode ser explicada, em parte, pela experiência da metrópole e das temáticas por ela sugeridas desde a modernidade, que partem do movimento ativo do flanêur até a passividade alienante do zapper. Instaura-se na narração um signo privilegiado de errância ou exílio, de não-pertencimento dos sujeitos, uma espécie de mal estar da civilização que também estará refletido nas relações de gênero e na suspensão dos tabus sexuais.

Ao assumir marcas de produção originadas na modernidade, os projetos estéticos deslizam para uma indeterminação produtiva com a prática cada vez mais elaborada do improviso e do fragmentário ${ }^{1}$. Parte do niilismo da pós-modernidade encontra tamanha repercussão nas obras literárias a ponto de aprofundar o sentimento de perda de sentido dos objetos representado pelo conceito de insignificância -, sobretudo ao promover uma fusão lacerante dos seres e das coisas na massa anônima da grande cidade.

Para apresentar essa vertente literária do espaço urbano talvez seja possível remeter ao conceito de discurso esquizofrênico, proposto por Tzvetan Todorov, definido pelo teórico como um texto que fracassa na

${ }^{1}$ COMPAGNON, Antoine. Os cinco paradoxos da modernidade. Belo Horizonte: UFMG, 1999. evocação da realidade ${ }^{2}$. A desconstrução da identidade una e coerente do sujeito metropolitano contribuiria para que o trabalho de referência fosse perdido e, com ele, todas as certezas. Em vista desse contexto seria preciso efetuar uma espécie de análise indeterminista de uma sociedade de igual qualidade, marcada pelo fractal, o aleatório, o exponencial, a massa crítica, os fenômenos extremos e as relações de incerteza com o pensamento ${ }^{3}$. É com semelhante olhar que os textos de João Gilberto Noll podem ser esquadrinhados criticamente.

O escritor gaúcho, ao debruçar-se na fruição do desejo, faz a escrita engendrar o erotismo e o gozo em uma região de sombra, margem ocupada por corpos duplos, ambivalentes e sem nome. Noll aplica uma das características do novo sujeito metropolitano a personagens desterritorializadas, marginais em relação ao centro urbano, mas que emergem das ruínas do entorno e do que é tornado invisível pela sociedade. Para além da representação das fábulas de incesto, os acidentes da carne assumem um posicionamento menos moral, porque libertino dentro do nonsense instaurado pelo deslizamento sexual. Com isso, o efeito narrativo parece manter um tipo de fricção estética, e mesmo esquizofrênica, em torno das conseqüências ativistas e teóricas surgidas tanto com a ascensão do

${ }^{2}$ TODOROV, Tzvetan. Os gêneros do discurso. São Paulo: Martins Fontes, 1980. p. 75.

${ }^{3}$ BAUDRILLARD, Jean. A troca impossivel. Rio de Janeiro: Nova Fronteira, 2002. p. 24. 
feminismo quanto com as teorias dos gêneros e suas proposições de outros roteiros sexuais para o corpo.

O romance $A$ céu aberto faz uso da literatura para representar textualmente os espaços provisórios de um corpo de sujeito e de escrita. Ainda que se movimente de um lado a outro dos gêneros sexuais tradicionais, o masculino e o feminino, a presença de um corpo travestido desestabiliza as identidades heterossexuais autoritárias ao não optar pela fixidez de nenhum gênero e mover-se em uma passagem intermediária: a do travestido. Para os fins deste artigo, interessa enfocar a experiência ambígua do gozo e do corpo nas personagens do mencionado texto.

\section{O travestimento do gozo}

Os dois protagonistas de $A$ céu aberto não possuem nome próprio e são designados por um atributo genérico que as distingue por idade e os identifica em familiaridade: o irmão mais velho e o irmão mais novo. Sobre o segundo se desenvolve uma possibilidade imaginária para o tema arquetípico doppelgänger, pois da natureza de seu corpo adolescente emerge a sutil perversidade de uma coexistência dos contrários sexuais.

A imagem engendrada por tal princípio inaugura outra categoria do personagem duplo, a do travestido, que, longe de ser guiada pelos princípios persecutórios explorados pela estética romântica, desenvolve a narrativa a partir do esfacelamento pós-moderno das ilusões identitárias e da condição de não-pertencimento. Na contramão do efeito funesto das sombras, dos reflexos, dos sósias, da dupla personalidade e dos gêmeos, o risco de morte para o ser original pode ser traduzido na forma de ruptura e anulação dos limites sexuais, uma espécie de simbólico retorno à androginia primordial motivada pelo duplo ${ }^{4}$.

A nova categoria doppelgänger em foco não diz respeito ao sujeito homossexual que adota vestes e costumes do sexo oposto, não reflete qualquer comportamento de ordem bissexual, nem a realidade psicológica do transexual ou a tradição corporal do travesti. O travestido poderia ser empregado para descrever um corpo ambivalente em relação à sexualidade, no qual a anatomia não constitui um destino e o discurso não permite ao leitor identificar claramente qual a performance de gênero efetua o corpo descrito no romance.

O conceito de travesti, aliás, remete a uma condição teoricamente mais produtiva quando trata do artista que faz uso de vestimentas, disfarces e artifícios para se afigurar como do sexo oposto ${ }^{5}$. No jogo performático

4 Os mitos de fundação que descrevem o mundo originando-se do caos frequentemente apresentam divindades andróginas - contendo princípios do masculino e do feminino em sua natureza -, traço cultural que dota de bissexualidade os ancestrais da humanidade. MIGUET, Marie. Andróginos. In: BRUNEL, Pierre (org.). Dicionário de mitos literários. Tradução de Carlos Süssekind [et. al.] 3. ed. Rio de Janeiro: José Olympio, 2000. p. 26.

${ }^{5} \mathrm{O}$ travestimento e a substituição voluntária de identidade são imagens comuns na mitologia dos duplos homogêneos. Cf. BRAVO, Nicole Fernandez. Duplo. In: BRUNEL, Pierre (org.). Dicionário de mitos literários. Tradução de Carlos Süssekind [et. al.] 3. ed. Rio de Janeiro: José Olympio, 2000. 
construído por meio do travestissement, a ação transformista, a representação torna-se uma alegoria da superposição das sexualidades ${ }^{6}$, muito embora frequentemente ocorra à custa de um gendramento estereotipado.

A narrativa de João Gilberto Noll consegue escapar ao clichê porque faz uso do travestido para instaurar a flutuação amoral e desgendrada da sexualidade. A fragmentação da identidade sexual dá-se, principalmente, por força do alheamento moral experimentado por um corpo que não encena qualquer conflito entre as pulsões afetivas (natureza $\mathrm{x}$ cultura, homem $\mathrm{x}$ mulher, alma x carne, amor x sexo), penetrando sutilmente em uma espécie de ataraxia.

Ecos do corpo transviado podem ser encontrados na preposição latina trans, enunciadora de um modelo que corrompe as matrizes discursivas de sexo e de gênero e se atira aos desejos sensuais da carne, o transexual. Intercambiável com o travestido, esse modelo de corpo duplicado aparentemente não oferece conflito entre as diferenças anatômicas, seguindo por um caminho de desconformidade em relação às determinações biológicas (identificadas pelo sexo), culturais (representadas pelo gênero) e psicológicas (motivadas pela orientação sexual).

\footnotetext{
${ }^{6}$ Semelhante superposição da sexualidade, de acordo com o conceito de travesti enunciado neste trabalho, já foi experimentada de forma magistral na literatura brasileira em Grande sertão: veredas, de João Guimarães Rosa. No romance está representada a experiência da falta do gozo por conta da tensão homoerótica e moralmente proibitiva entre o narrador e Diadorim, a mulher travestida em jagunço.
}

O descompasso inerente ao travestido o constitui como um corpo que é, a um só tempo, o mesmo e o outro ${ }^{7}$. De acordo com a narrativa tradicional, o duplo deveria perseguir seu original e usar meios escusos para usurpar definitivamente o lugar de trânsito e permanência pertencente a ele. Entretanto, como resultado das transformações culturais, sociais e históricas do mundo, semelhante tradição modificou-se na narrativa contemporânea e corporificou outras formas, das quais merecem destaque o duplo de instância projetiva, o replicante e o clone ${ }^{8}$. Apesar da atualização procedimental no imaginário, as histórias baseadas nas versões contemporâneas do arquétipo não se afastam do princípio atemorizante de que o Mesmo ocupe o lugar do Outro.

De outra sorte, o travestido, ainda que seja aparentado de semelhante linhagem, efetua uma performatividade na qual o eu e o eu-tu desejam conviver pacificamente no mesmo espaço. A narrativa traduz a condição incoerente do corpo:

${ }^{7}$ ROSSET, Clément. O real e seu duplo: ensaio sobre a ilusão. Tradução de José Thomaz Brum. Porto Alegre: L\&PM, 1988. p. 33.

${ }^{8}$ Há poucos estudos teóricos sistemáticos a respeito das possibilidades de figuração do duplo na literatura contemporânea, nenhum detalhado como o desenvolvido por Otto Rank. Observando tal lacuna, apresentei um paper na IX ABRALIC (Porto Alegre, 2005) no qual tentei trabalhar com quatro categorias modernas: o projetivo, o replicante, o clone e o travestido. 
E o meu irmão, o meu irmão que presumivelmente hibernava dentro dela (...) Não pude deixar de rir ali quando lembro dele: uma farsa montada por mim? Ou esse irmão havia de fato existido com sua própria face, tornando-se de repente apenas uma imagem turva para que a face de minha mulher pudesse reinar...O certo, o certo é que ainda lembrava muito bem...eu apenas o levara ao campo de batalha para pedir ao nosso pai algum amparo para a saúde dele. Acabou o meu irmão vestido de noiva ou coisa do gênero $(. . .)^{9}$

Parafraseando e aplicando o conceito discursivo de Todorov seria possível afirmar que a incoerência corporal encenada pelo texto de Noll é uma das razões pelas quais o estatuto da referência seria impossível ${ }^{10}$. Além disso, a permanência fora dos padrões parece dar-se menos pelo desejo de gozar no lugar do Outro que pela vontade de experimentar o gozo do outro no mesmo corpo, ainda que seja à força.

A separação da sexualidade e do gozo em dois corpos diferentes, o masculino e o feminino, remete à tradição judaico-cristã do Gênesis e à história de Adão e Eva: o homem feito da matéria inanimada, o barro, dá origem à mulher, a partir de uma parte de si, a costela. Ainda que seja uma metonímia do corpo masculino, Eva tem um corpo de formas distintas e que ensaia outras possibilidades de gozo.

\footnotetext{
${ }^{9}$ NOLL, João Gilberto. A céu aberto. São Paulo: Companhia das Letras, 1996. p. 138.

${ }^{10}$ TODOROV, op. cit., p. 75.
}

A exegese judaico-cristã, de acordo com Marie Miguet, oculta o princípio da bissexualidade de Deus e de sua criatura, Adão Cadmon, feita à imagem e semelhança do criador. Os traços narrativos que documentariam essa história de androginia primordial poderiam ser identificados na fábula de ruptura da perfeição corporal - provocada pela separação dos sexos - e na da expulsão do Jardim do Éden com o Pecado Original ${ }^{11}$. A representação mitológica do nascimento dos sexos, assim transmitida ao longo do tempo pela cultura ocidental, é fundadora da cartografia biológica e sexual da heterossexualidade, código de comportamento que transforma a relação entre homens e mulheres em prática natural e normativa.

Contrariando semelhante disposição, o travestido age como transgressor da normatividade ao escapar do campo dos rótulos e das definições convencionadas e lançar-se num espaço flutuante, à deriva dos discursos heterocêntricos. A condição de marginalidade é angariada porque o travestido não se afirma como corpo-homem ou corpo-mulher, mas permanece em trânsito na tensão sexual e no gozo de ambos. Assim, aquilo que poderia constituir uma experiência de conflito com normas de gênero torna-se um apreciado artifício de ambigüidade, tanto sexual quanto textual, sancionado pelo irmão mais novo: "prefiro assim, sempre na dúvida"12.

A voz narrativa encerra-se em uma dobra erótica como forma de constatação de uma experiência sexual que assoma às margens, faz das

\footnotetext{
${ }^{11}$ MIGUET, op. cit., p. 26.

${ }^{12}$ NOLL, op. cit., p. 110.
} 
páginas um movimento trêmulo, de uma carne trêmula. A alteração das regras do jogo permite que o objeto de gozo deixe de ser decodificado segundo os termos em que estava anteriormente inscrito. Por meio de um estatuto que não é definitivo, ao sujeito do gozo é oferecida uma pluralidade de formas de prazer. O travestimento do corpo, em vez de ser repudiado por repressores psíquicos, morais ou sociais, estabelece uma particular comunicação entre o sujeito desejante e seu objeto desejado.

O que o autor explora é uma forma de subjetividade, via artefato textual, centrada no erotismo escrito e inscrito na arqueologia do hedonismo sexual. A reinvenção do corpo é acompanhada por um jogo irônico de dessacralização de imagens, responsável por profanar os signos sagrados e os institucionalmente masculinos. Serve de exemplo o trecho no qual, ao sair de uma tenda no front de guerra, lugar da virilidade, o irmão mais novo surge aos olhos do mais velho como mulher, vestido de noiva para casar com um soldado, imagem descrita como semelhante à da 'fêmea em dia de primeira comunhão':

(...) pergunto, quem é esse irmão se quando voltei a vê-lo ainda em plena guerra ele já era outro, eu conto: quando voltei a vê-lo dessa vez de longe, eu atrás de um tronco no alto de um morro nas imediações do acampamento militar, no começo nem o reconheci, ele saindo da tenda vestido de noiva, é, mas não não era noiva depois percebi, o corpo dele ainda não comportava um vestido festivo de mulher plenamente desenvolvida, o meu irmão ainda era mirrado, adolescente, pensei então se aquele vestido e aquele véu descendo de uma grinalda meio prateada não era de primeira comunhão, os oficiais do exército do meu pai ladeavam o seu corpo franzino e eles iam todos ao encontro de um homem loiro com uma reluzente e estranha farda postado na outra margem do acampamento: trazia a aparência ardorosamente expectante e a sua farda reluzia ao sol, e ele deu alguns passos em direção aos passos do meu irmão nessa altura com a barra da saia toda cheia de lama ${ }^{13}(\ldots)$

Não apenas o mais novo, mas o irmão mais velho também desconstrói o mito épico do macho varão ao beijar a face de um soldado e mansamente aceitar fazer sexo oral em um general:

O homem então sentou-se de novo na cadeira feita da mesma lona de tenda, abriu as pernas, o negócio dele cada vez mais empinado, e ordenou que eu me ajoelhasse, e de imediato empurrou a minha cabeça ao encontro do negócio dele que eu fui obrigado a abocanhar, para cima e para baixo, quando para baixo o negócio dele encostava na minha garganta e ficava (surpreendentemente para a idade do homem) cada vez mais grosso e comprido, e eu bem verdade não sabia direito o que sentir, achar daquilo tudo, eu permanecia ali $(\ldots)^{14}$

\footnotetext{
${ }^{13}$ NOLL, op. cit., p. 61-62.

${ }^{14}$ NOLL, op. cit.,p. 53.
} 
No cenário nonsense e destruidor proporcionado pelo combate bélico - 'uma guerra que eu não sabia para que servia'15 - das barricas e das trincheiras, a céu aberto no campo de batalha, da mesma forma que a razão humana esfacelou a crença nas utopias no progresso, o atributo fixo da virilidade desapareceu ou contaminou-se de incerteza. Há um caráter metafórico que contorna a realidade das personagens do romance, pois a partir dela os critérios fixos de sexualidade perdem-se em meio aos escombros e, como uma espécie de ritual de passagem, devolve-se o corpo em ruínas ao caos inicial da criação:

Na margem um pouco mais à frente um soldado estirado, parecia ferido. De fato tinha sangue no peito, gemia. Me ajoelhei ao lado dele, abri a camisa com a estamparia de camuflagem. Ele tinha pequenos seios, só um deles via-se inteiro, o outro estava quase todo estraçalhado por um tiro. Tirei o capacete dele: cabelo rente, barba por fazer. Mas um corpo a me trazer a lembrança do meu irmão....Mas um corpo que parece masculino e que em meio ao exército em meio à guerra é revirado pela mão de algum deus que lhe puxa lá de dentro a mulher até então enterrada? [sem grifo no original $]^{16}$

Permanecendo em um caminho incerto, depois de deserdar do serviço militar, o narrador reencontra o irmão em uma igreja, usando saia, exercendo

\footnotetext{
${ }^{15}$ NOLL, op. cit.,p. 10.

${ }^{16}$ NOLL, op. cit., p. 139.
}

as funções de coroinha e amante de padre. Com isso, Noll oferece ao leitor uma atitude dessacralizadora do território puro da religiosidade:

(...) pois o meu irmão está aqui neste instante a me olhar e não é mais essa criança que acabei de descrever vazando lágrimas não, e também não está mais na pele daquele que vivia a estranha cerimônia no acampamento militar pois já tirou o vestido de noiva e me olha parado porque já faz tempo que não me vê, mas continua de saia o danado, vestido de coroinha, por baixo de uma espécie de batina vermelha, por cima de uma paramento branco com mangas largas rendadas e decote em $\mathrm{V}$ na frente e atrás...é que entrei numa dessas igrejas perdidas nas redondezas de cidade e peguei o rabinho da missa $(. . .)^{17}$

O elemento religioso, assim, age como veículo para uma situação imoral ao mesmo tempo em que assume a condição de memória, de refúgio e de salvação ${ }^{18}$ das personagens. É no interior da igreja que o narrador aceita

\footnotetext{
${ }^{17}$ NOLL, op. cit.,p. 67.
}

${ }^{18} \mathrm{O}$ discurso de Noll dessacraliza o religioso a partir do elemento irônico. Arthur, por exemplo, depois de uma batida policial em uma casa de massagem gay, acusada de exploração de menores, é cuidado por uma personagem negra que alude à figura da Nossa Senhora Aparecida: "[...] só sei que quando consegui ver da calçada um policial cheio de documentos na mão devolver a identidade de Arthur e ele então sair devagar da delegacia falei para mim mesma vou salvar este homem, eu vou trabalhar na casa dele e não deixar que nada de mal the aconteça. Aparecida conta as peripécias e contraperipécias que a empurraram até a pessoa de Arthur e que o fizeram acreditar que seria ela Aparecida a melhor empregada que ele poderia ter". Aparecida torna-se a empregada protetora de um pederasta. NOLL, op. cit., p. 31. 
um processo de transformação iniciado com a doença do irmão mais novo, uma metáfora para a passagem do corpo masculino ao sexo oposto:

O meu irmão não tirava a vestimenta de sacristão, pelo jeito estava gostando de andar de saia. Ganhara uma suavidade no olhar, os cabelos caídos de um lado da face, e eu ali por bons minutos com um joelho no chão analisando esse irmão que não reconhecia mais, quem sabe andava se transformando em minha irmã.... (... $)^{19}$

O borramento das regras e dos limites sexuais, condição imposta à narrativa no retorno simbólico ao andrógino, poderia ser comprovado pelas fotografias encontradas pelo narrador na gaveta do padre, pedaços de matéria visual afeitos mais à ficção de uma existência que à representação objetiva ${ }^{20}$. Ao manusear a iconografia de mutação do travestido, o irmão mais velho registra:

(...) e surpreendi lá dentro sob uns papéis de cartório umas fotos do meu irmão nu, algumas tiradas dentro do caixão acetinado de roxo, meu irmão se masturbando aqui, de bunda para cima ali, mamilos crescidinhos, seios púberes, resultado de hormônios considerei, mas nada que se pudesse notar com tanta nitidez debaixo do tecido da

\footnotetext{
${ }^{19}$ NOLL, op. cit., p. 68.

20 Jean Baudrillard afirma que a imagem-foto, não sendo uma representação da realidade, é uma ficção, sobretudo por não captar aquilo que é/aquilo que existe, mas por fazer o shot do que não deveria ser/o que não deveria existir. BAUDRILLARD, op. cit., p. 146,148.
}

camisa; uma foto do meu irmão segurando com as duas mãos a vela, os lábios roçando a chama, uma outra num ângulo a partir das coxas, em nenhuma foto viam-se pêlos, na certa o padre raspava o garoto porque ele possuía idade suficiente para pêlos pubianos, e agora estava ele ali com a glande querendo se encorpar, os mamilos como que inchados, e tudo isso me deu a impressão de que o meu irmão andava se realizando dessa forma, que era isso mesmo que ele queria da vida, ser motivo de deleite feito a única fruta do mundo no ponto. ${ }^{21}$

O discurso textual parece afirmar que o verdadeiro desvio não está contido nesse corpo inventado nas imagens e, sim, na ficção da coerência sexual heteronormativa. Desfeito o modelo arquetípico do comportamento entre os sexos, a morfologia do corpo travestido da personagem recupera certo "conteúdo androgínico",22 para dispor de uma ação erótica mais potente em relação às possibilidades do gozo e da afetividade. E por tornar-se uma potente máquina de desejo, o narrador aceita o jogo subversivo da transgressão das diferenças sexuais e percebe o irmão/irmã como símbolo da perfeição, o sonho mítico da reunião do masculino e do feminino em um só ser.

\footnotetext{
${ }^{21}$ NOLL, op. cit., p. $72-73$.

${ }^{22}$ MIGUET, op. cit., p. 27.
} 


\section{O incestuoso gozo}

Por meio da escrita literária, o leitor participa da fluidez do desejo e do prazer em instâncias narrativas que colocam uma série de princípios morais em crise ${ }^{23}$. São os tabus sexuais que ganham o campo discursivo. Em A céu aberto, o narrador pensa eroticamente no irmão; deseja sexualmente um pederasta, amigo de infância do pai; casa-se com o irmão travestido em irmã; estupra com violência o amante da esposa-irmão; exilado e clandestino, serve de escravo sexual a um velho lobo do mar. Desta última aventura do sexo surge a metáfora do romance de João Gilberto Noll. O navio ${ }^{24}$, representação psicanalítica do corpo, é a alegoria profícua para uma sexualidade que só pode aportar em terra estrangeira. O narrador, sem que tenha estabelecido por si mesmo uma linha geográfica de sentido, faz um avanço bêbado pelo caminho da loucura, do sono e da vigília, marcas

${ }^{23}$ Hilda Hilst propôs um perverso jogo de metalinguagem em $O$ caderno rosa de Lory Lamb. Ao emprestar a uma menina de oito anos a voz para registrar seus inventados relacionamentos pedófilos, a autora coloca o leitor em crise. Até ser descoberta, ao final do livro, a intenção inocente da narradora em escrever algo que ajude o pai a ser 'mais vendável', o interlocutor do texto se depara com uma série de possibilidades monstruosas - uma criança tão cedo ser afeita ao sexo, ao dinheiro e aos bens materiais. HILST, Hilda. O caderno rosa de Lory Lamb. 2. ed. São Paulo: Globo, 2005.

${ }^{24}$ A edição da Companhia das Letras traz como imagem de capa a figura de um navio sobre a espuma, de autoria do artista plástico e fotógrafo Roberto Stelzer. sugeridas pelas profissões que ocupa na trama: as de sentinela e vigia noturno $^{25}$.

Por meio dessas estratégias discursivas a literatura de João Gilberto Noll, explorando artisticamente a reinvenção sexual, revela uma espécie de conivência e cumplicidade com o erotismo incestuoso do narrador pelo irmão mais novo: "Eu já era um homem apaixonado, ainda mais por saber que aquele corpo percorrera um itinerário tortuoso para chegar até ali"26. $\mathrm{O}$ desvio, a subversão e a corrupção da carne são conceitos colocados de lado diante de um corpo iluminado por uma permissividade erótica sem limites, semelhante àquela consciência sem impedimentos do desejo enfrentada por algumas das personagens de Caio Fernando Abreu: "Eu era apenas um corpo que por acaso era de homem gostando de outro corpo, o dele, que por acaso era de homem também",27.

Ainda que trate de um tema que, em princípio, é monstruoso ${ }^{28}$, Noll não faz uso de sutilezas para abordar uma relação entre irmãos, preferindo

${ }^{25}$ A condição entre o sono e a vigília pode ser ilustrada pelo seguinte trecho: "Tudo se embaçava em volta de mim. Acho que já disse, andava meio cansado por causa do trabalho de vigia noturno, nunca dormia horas suficientes, me sentia um pouco remando contra a corrente entre o m eu despertar e a hora de chegar no paiol, quando aí sim, aí ficava uma calmaria espantosa, tudo parecia parar um pouco para ficar comigo [...]". NOLL, op. cit.. p. 110 .

${ }^{26}$ NOLL, op. cit., p. 76.

27 ABREU, Caio Fernando. Terça-feira gorda. In: São Paulo: Companhia das Letras, 1995. p. 51

28 O Hermafrodita, curiosamente, é retratado 
tratá-la sob a prática da instabilidade do gênero e da urgência do prazer. Por serem elementos de uma mesma família mitógena, o incesto, o androginismo e a gemealidade criam uma forma de fantasmagoria, uma transgressão de ordem, por oporem-se ao que é dado pelo meio ${ }^{29}$. Deriva disso uma realidade paradoxal porque a transgressão apenas existe se há uma lei ou proibição sexual instituída; a lei, por sua vez, apenas é fortalecida com a transgressão, movimento que cria um tipo de mercado negro, paralelo e sem fim para a realização do sexo e a circulação do desejo. Além disso, a concepção do incesto como prescrita pelos antigos mitos não é marcada pela imoralidade porque faz referência aos tempos adâmicos do Gênesis e à linhagem superior dos deuses ${ }^{30}$.

O irmão mais velho exprime e cumpre a vontade de possuir um corpo de homem afundado num corpo de mulher, de um sujeito sexual que rompe a figura da normalidade e discursivamente restaura a unidade perdida do masculino e do feminino. A dupla postulação erótica - homem/mulher e irmão/irmã - inspirada pela relação entre os irmãos roça na fantasmagoria de uma coexistência tensa dos gêneros/sexos:

Dentro daquele corpo de mulher deveria existir a lembrança do que ele fora como homem e boliná-lo como

da sexualidade é descrito como o exercício de um prazer inumano - irracional, abominável e horrendo.

${ }^{29}$ MIGUET, op. cit., p. 35.

${ }^{30}$ CHEVALIER, Jean; GHEERBRANT, Alain. Dicionário de símbolos. Tradução de Vera da Costa e Silva [et. al.] 16. ed. Rio de Janeiro: José Olympio, 2001. p. 504. eu fazia naquele instante deixava em mim a agradável sensação de estar tentando seduzir a minha própria casa, onde eu encontraria o meu irmão quem sabe em outro momento. Não, o meu irmão não morrera naquele corpo de mulher, ele permanecia lá dentro esperando a sua vez de voltar, e eu beijava um pedaço de seio à mostra e desamarrei a camisola e disse que queria um filho dela e disse que não queria um filho dela pois estava bom assim sem filho nem nada, para que uma criança entre nós dois se uma outra poderá surgir daí na pele do meu irmão? ${ }^{31}$ [sem grifo no original]

A performance de gênero do narrador, masculina, não chega a ser questionada como dentro ou fora dos padrões tradicionais, uma vez que a única regra imposta é a de não impedir o fluxo do gozo sexual, desencadeado por uma voracidade inominável. A sedução da própria casa é uma das formas de representação metafórica do incesto, da união dos semelhantes, da exaltação da essência interior ${ }^{32}$.

Rumando para um lugar onde e um tempo quando, a narrativa toma o travestido como um corpo de travessia do gozo, emblema de perfeição andrógina: "cheguei a pensar que ele poderia ser a mulher com quem eu sempre sonhara" ${ }^{, 33}$. Assim, o que pertence à esfera abstrata do sonho se concretiza com o deslizamento do desejo para um lugar de realização do instinto e de concretude do corpo.

\footnotetext{
${ }^{31}$ NOLL, op. cit., p. 76-77.

${ }^{32}$ CHEVALIER; GHEERBRANT, op.cit., p. 504.

${ }^{33}$ NOLL, op. cit., p. 73.
} 
O percurso tortuoso do travestido, conforme pontuado pelo narrador, deixa evidente que a noção de duplo funciona como aparato de sedução e erotismo do texto, notadamente em relações de alteridade que fundem contraste e distinção. O discurso textual do corpo bifurca-se, assume o princípio reversível do eu-tu, espaço no qual o cheiro do homem surge no vestuário da mulher, em que a mulher surge na pele do homem, desenhando uma cartografia enigmática:

De tarde me levanto e vou pela casa sentindo o cheiro de macho do meu irmão. Ele anda por aqui, nem se for só o seu odor pesado e suarento que ficou impregnado em tudo que usou e tocou, olha essa cortina que pego e levo até o nariz, sim, ele tocou aqui nessa fazenda grossa e encardida. Se pudesse sentir o meu próprio cheiro sentiria quem sabe que é igual, o mesmo do meu irmão esse cheiro de macho continuamente ativo como se nele vibrasse constantemente um âmbar saturado coberto do sal do suor, quisera eu que ele voltasse e me saturasse ainda mais desse seu cheiro, eu como que me prostraria no chão sem fazê-lo, a cabeça levemente pendida, uma gota de suor $(. . .)^{34}$

O jogo de presença e ausência do masculino no corpo da mulher empresta a mesma oscilação ao trato com o parentesco incestuoso, pois na diluição das certezas do narrador as imagens opostas encavalgam-se: "naquela penumbra descobri de vez que era o meu irmão sim a minha

\footnotetext{
${ }^{34}$ NOLL, op. cit., p. 79-80.
}

mulher" 35 . Observado na sombra, metáfora da ignorância, o travestido confunde e estranha o olhar porque não assume nenhuma identidade, permanecendo com a sexualidade sem centro definido. A subjetividade é perturbada, quase sempre postergada, mantida em suspenso.

Como procedimento de provocação, a narrativa de Noll escolhe o caminho do excesso instaurado pela pós-modernidade para representar um tempo no qual os valores pendem para um desequilíbrio de crise muito próximo do niilismo. O travestido representa parte de uma crise contemporânea das identidades, sobretudo com o afigurar de um estado de incerteza geral das coisas e de refluxo de todas as formas de afeto. A personagem macho-fêmea de $A$ céu aberto, com sua forma ambígua de sexualidade, penetra no espaço intermediário do amor, da busca da felicidade, da realização total do gozo. Na malha narrativa em que o autor captura suas criaturas é possível entrever estes resquícios do mito andrógino: o modelo da perfeição do prazer e a fonte do escândalo sexual.

\section{O gozo à força/A força do gozo}

Culturalmente, de acordo com a perspectiva ocidental, a figura do travestido incorpora o Mal, é uma fonte de prazer inumano, não o símbolo da abundância desejável do primeiro Adão. A contraposição entre Mal e Bem é um forte traço da sociedade ocidental embora se trate, na verdade, de uma

\footnotetext{
${ }^{35}$ NOLL, op. cit., p. 74 .
} 
ilusão de ótica, pois ambos os pólos de força, assim como o masculino e o feminino, são assimétricos: "não são espelho, nem o complemento, nem o contrário um do outro" 36 . A oposição binária não serve para a realidade dos termos assimétricos porque estes não dão lugar à diferença, isto é, a fraqueza nas relações de diferença entre o gozo do homem e da mulher está no fato de que o espaço da oposição não existe.

O retorno a um tempo mítico de confusão bissexual constitui um desejo utópico para os códigos sociais, mas o questionamento contemporâneo da sexualidade, ao separar as noções de sexo biológico e de gênero, de certo modo já conseguiu instituir o prazer como regra de um jogo sem fim. É possível que o combate bélico de $A$ céu aberto também seja metáfora para a antiga guerra dos sexos, da qual o narrador é um desertor, justamente porque prefere o exílio à ceder a polarização das forças do desejo [ativo/passivo, macho/fêmea, afinidade/consanguinidade].

Assim, a margem do social torna-se o território privilegiado do pertencimento, lugar no qual também está situado o travestido, o incesto e o estupro, ou seja, é o campo dedicado ao negativo e aos regimes patológicos da consciência. João Gilberto Noll empresta ao seu narrador a violência intensa do gozo e a duração no corpo de uma indiferença perigosa em relação ao Outro. A moralidade, o ciúme e o amor desaparecem da psique desde que outras possibilidades de gozar sejam mais fortes que os princípios ordenados pelo superego e pelo domínio visceral das paixões.

\footnotetext{
${ }^{36}$ BAUDRILLARD, op. cit., p. 99-100.
}

A experiência sexual coletiva no estilo ménagè a trois, por exemplo, é recebida na narrativa com passividade e indiferença afetiva, sobretudo porque o corpo agregado guarda em si a hereditariedade do desejo:

Quando chego em casa de manhãzinha minha mulher está dormindo com um homem na cama de casal. [...] Eu e ele nos olhamos enquanto minha mulher ressona de bruços. As feições dele parecem impressionantemente com as de alguém que não me ocorre. [...] Ah! Falei, como se ao mesmo tempo estivesse distendendo meu braço e meu peito do lado do coração, ah! você é filho de Arthur, do velho pederasta que me abrigou durante as fatídicas enchentes daquele ano de....Sim, ele respondeu sentandose na cama; sou filho do velho pederasta Arthur. [...] Ela estava agora em pé, entre nós dois, e perguntava se já nos conhecíamos. Sim!, me escapou a mentira e valendo ficou. O rapaz me olhou, parecia que eu estava vendo Artur. Artur tinha instantes, não mais que instantes efeminados. Esse rapaz não parecia tê-los. Nós três tomamos o parco café da manhã como se fôssemos uma família de anos ${ }^{37}$.

O bissexual, o travestido e o amante convivem juntos como se fizessem parte de uma harmoniosa cena familiar, ligados pela vontade de exploração das necessidades do desejo. O filho de Arthur, muito embora tema o 'espectro pederástico do pai', aceita sem revolta a violência sexual e sádica da passividade homossexual que o narrador lhe impõe, manifestando uma

\footnotetext{
${ }^{37}$ NOLL, op. cit., p. 85.
} 
espécie de indiferença quanto aos processos pelos quais se pode atingir o gozo:

[...] sim eu espalmei a mão na bunda do garoto, ele quis reagir notei na respiração quase arrebentando, depois foi the caindo uma resignação diante do fato de estar sendo bolinado por mim na nádega, depois começou a gotejar pela cara e pescoço um suor cheirando, penetrante, depois as nossas roupas rasgadas a dele e a minha, a mesma fúria: cuspi fundo na palma da mão, untei meu pau de saliva, o pau entrou de um golpe, o rapaz berrou, a cotovia e a coruja e o quero-quero e o carpideiro, tudo isso respondeu aos berros, esqueci não quis saber só tinha ouvidos para o meus próprio ronco, côncavo, interno, avarento, miserável e só. Quando eu próprio gritei enfim olhei para o meu púbis e o vi todo banhado de sangue, no começo não entendi mas logo me dei conta de que eu arrebentara o cu do garoto que na certa não era dado a permitir que enfiassem aquelas rijas postas de carne pelo seu anus, mas a verdade era que ele agora não mais emitia expressão de dor, vi que tirava completamente a roupa para entrar no rio em silêncio, como se fosse limpar o estrago como merecido estoicismo, tratar do que acontecera como tinha de ser, despido de qualquer lamento... ${ }^{38}$

A matéria narrada está muito próxima de ilustrar esta definição de Jean Baudrillard: “o estupro verdadeiro não é gozar à força, mas fazer alguém gozar à força" 39 . Assim, o irmão mais velho, ao forçar que o filho de Arthur goze, institui o princípio abstrato da moeda viva na narrativa. Para que obtenha a riqueza - o gozo de um homem singular - pela manutenção do signo da riqueza - a permissão para o ménagè a trois -, o narrador procura violentar a parte inalienável do filho de Arthur, a porção viril da carne, “forçar em seu cerceamento o que só se pode dar na cumplicidade amorosa" $^{40}$ :

No dia seguinte acordei cedo para os meus padrões. Onze da manhã. A calça do garoto jogada a uma cadeira na sala. Peguei-a, manchas de sangue nos fundilhos. [...] Fui fazer café. O garoto apareceu na cozinha. [...] É tão simples assim, eu disse para ele. Ele acho que não ouviu, falou:

'Tomei um ácido de madrugada e não senti nada'.

'A que horas?' eu quis testar.

'Quando cheguei em casa depois do bosque'.

'Não sentiu nada?'

'Nada, salvo um desacordo total com aquilo que eu via, o quando onde eu durmo com seu armário feio; e depois um breve sobressalto e alguém batendo na janela do quarto como que numa emergência, alguém que pelo jeito precisava de um pronto amparo enquanto eu não, eu estava naquele instante no tal sobressalto e não me interessava acolher ninguém, estava ali na cama esperando que brotasse um abalo sísmico que deixasse tudo em erosão e não tivéssemos onde mais segurar além das escuras

\footnotetext{
${ }^{38}$ NOLL, op. cit., p. 105-106.
}

\footnotetext{
${ }^{39}$ BAUDRILLARD, op. cit., p. 127.

${ }^{40}$ BAUDRILLARD, op. cit., p. 127.
} 
escarpas anãs que se formavam raivosas no solo entendeu?

Para aceitar a passividade desempenhada em seu papel masculino, o filho de Arthur faz uso do ácido lisérgico para salvar-se da brutalidade da noite, entregando-se às promessas de alucinação da droga. Entretanto, só consegue sentir a realidade como uma espécie de 'desacordo total', sensação provavelmente motivada pela liberação da fantasmagoria feminina em seu corpo, isto é, pelo reconhecimento da hereditariedade do espectro pederasta do pai.

O jogo da moeda viva instituído entre os dois homens permite que gozo/desejo de um seja atingido por meio do gozo/desejo do outro, signos que não possuem um valor real no sistema de valores e apenas podem ser trocados mutuamente. O momento do gozo, entretanto, sobrevive por um instante apenas ao passo que a violência simbólica ao sexo biológico e ao gênero permanece no corpo como corrupção, de modo irreversível.

À troca mercantil opõe-se a troca simbólica. A sedução empreendida pelo narrador diz respeito ao desvio dos objetos para o domínio simbólico das formas e o encaminhamento deles para a troca simbólica, não sendo o domínio material do poder via estratagema sexual. O Crime Original, nesse sentido, só pode ser o da sedução ${ }^{41}$. O fundamento moral do capitalismo gera a crença de que não existe nada a que não se possa atribuir um valor e,

${ }^{41}$ BAUDRILLARD, Jean. Senhas. Tradução de Maria Helena Kühner. 2. ed. Rio de Janeiro: Difel, 2007. p. 26. consequentemente, fazê-lo trocar-se por alguma coisa. Assim, a transformação à força do gozo em moeda viva faz o objeto do gozo participar do jogo imoral da troca simbólica, da proliferação sem fim dos signos, da substituição ininterrupta de um signo por outro.

A desestabilidade do desejo, provocada pelo movimento transgressor dos discursos normativos da sexualidade em sua busca pela potência do gozo, também atinge um limite crítico. A destruição do corpo do irmão-irmã, assassinado pelo narrador ao final do romance, pode ser tanto resultado de uma ação niilista quanto um tipo de drama passional, originado da exaustão do jogo com o desejo e no qual prevalece a lógica: "se o objeto lhe escapa, então é preciso que ele falte definitivamente, isto é, que ele desapareça" ${ }^{42}$. O narrador, pois, decide estabelecer à força a ausência do gozo para que a força do próprio desejo de gozo não o destrua ${ }^{43}$ : “e um tesão incontrolável que nas minhas orações noturnas debaixo de uma camada fria de suor eu pedia que cessasse sim que cessasse esse tesão que já não cabia mais em mim, que ia acabar comigo, que ia me matar",44.

${ }^{42}$ BAUDRILLARD, A troca impossivel, p. 73.

${ }^{43}$ Marie Miguet pontua o seguinte: "O caminho da perfeição androgínica tem como recompensa a mutilação, a solidão, a reprovação divina ou humana”. MIGUET, op. cit., p. 35 .

${ }^{44}$ NOLL, op. cit., p. 142 


\section{Metáfora transexual na pós-modernidade}

Ao contrário das primeiras modalidades do duplo na história da literatura, persecutórias daqueles de quem se duplicam, é o travestido que se faz perseguir, uma vez que é uma potente máquina de desejo. A inversão permite considerar que o livro de João Gilberto Noll faz a leitura do desejo e da satisfação em um mundo disforme e difuso. Aos fluidos do corpo estão misturadas a fluidez do amor e o esvaziamento da subjetividade moderna, fatos que o narrador comprova em seu trajeto oco por um mundo de excessos.

Jean Baudrillard, ao deter-se em semelhantes temas, afirma que a sociedade vive uma era de obscenidade, na qual há uma proliferação desenfreada e sem fim do social, do político, do estético e do sexual. Para ele, a pós-modernidade abriu espaço para o desenvolvimento dos fenômenos extremos, estes que acontecem além do fim, do excesso, da reação em cadeia que ultrapassa o limite crítico $^{45}$. A literatura de João Gilberto Noll traça caminho discursivo pela vertigem do êxtase, assumida pelos sujeitos narradores como forma de deslocamento subjetivo, movimento efetuado para fora e dentro de um mundo fragmentado próximo da perturbação sensível da loucura.

O êxtase do sexo é ser mais sexual do que o próprio sexo, ser hiperbólico, travestido, ser a reunião dos diferentes prazeres colocados em

\footnotetext{
${ }^{45}$ BAUDRILLARD, Jean. A ilusão vital. Rio de Janeiro: Civilização Brasileira,
} 2001. p. 51-52. um mesmo corpo, de modo atravessado. Seria possível dizer que o corpo duplicado, percorrendo formas e forças contrárias na verdade se dessexualiza, transforma a presença do sexo e do gênero em fantasmagoria e ilusão. Marcada pelo excesso, a libido rompe barreiras, deságua, invade outros lugares, assume a função de capitã do navio-corpo. O erotismo do travestido repousa nessa impossibilidade de uma presença real das coisas e seres, condição dramática da fantasmagoria, por causa da ausência definitiva dos próprios seres, na falta que é uma solidão de amor.

Afinal, foi com uma aura de conquista do mundo contemporâneo que a liberação sexual dissociou o sexo da procriação, proclamada pelo lema 'o máximo da sexualidade com o mínimo de reprodução'. No entanto, essa degradação de antigas proibições permitiu uma repercussão dúbia, na qual o sexo perdeu certo caráter específico e entrou num processo de confusão, contágio e indiscriminação ${ }^{46}$. As diferentes identidades sexuais ficaram visíveis e desejáveis, num tempo simultâneo, num lugar idem. Reside, nesse contexto, o próprio sonho da liberação sexual: "totalidade do desejo e de sua realização em cada um de nós, masculino e feminino ao mesmo tempo, sexualidade sonhada, assunção do desejo além da diferença dos sexos"47. Trata-se, pois, do hedonismo da carne experimentado pela personagem de João Gilberto Noll.

46 BAUDRILLARD, Jean. A transparência do mal: ensaio sobre fenômenos extremos. Campinas: Papirus, 1990. p. 12-13.

${ }^{47}$ BAUDRILLARD, A transparência do mal, p. 18. 
É no apagamento dessas diferenças, postas em pé de igualdade pelo desejo, que se encontra o narrador de $A$ céu aberto. Entregue a um destino sem preferências, ele não se pergunta quais corpos deve amar, afunda-se na normalidade sexual do libertino. Semelhante comportamento, postula Baudrillard, faz parte da natureza transexual, "não no sentido anatômico mas no sentido mais geral de travestido, de jogo de comutação de signos do sexo, e por oposição ao jogo anterior da diferença sexual, de jogo da indiferença sexual, indiferenciação dos pólos sexuais e indiferença ao sexo como gozo"48. A narrativa materializa esse aspecto da transexualidade com um espaço de sedução, num corpo duplamente sedutor, corpo de mulher, cheiro de homem, mulher-homem recendendo.

De certa maneira todos os sujeitos são simbolicamente transexuais, não no sentido biológico, mas no apelo por artifícios, por jogo de signos vestimentares, morfológicos e gestuais, característicos do travesti ${ }^{49}$. Ou pela artificialidade do disfarce, do fetiche, da mudança de sexo. Hoje, mais do que nunca, são os suportes e as próteses técnicas que permitem um retorno mínimo à unidade, depois que a mutilação divina separou o corpo em masculino e feminino e desfez a excelência da fusão dos contrários que o andrógino personificava.

\footnotetext{
${ }^{48}$ BAUDRILLARD, A transparência do mal, p. 27.

${ }^{49}$ BAUDRILLARD, A transparência do mal, p. 27-28.
}

Com a liberação sexual, os discursos dessa natureza deixaram de ser perversos ou devassos, pois o erótico, o pornográfico e o obsceno ${ }^{50}$ coexistem. A transgressão, em certo sentido, passou a vigorar como norma após o êxtase do sexo, porque esses corpos travestidos, transexuais, "vivem de signos exagerados, de signos carnívoros da sexualidade" 51 e precisam devorar o próprio amor. A sociedade fica a céu aberto, vacilando numa convicção sexual líquida porque o discurso amoroso também se liquefez no percurso tortuoso do corpo.

Estirada por esse trânsito de performance do corpo, a subjetividade torna-se uma expressão temporária e móvel, ligada ao fluxo interno do desejo e à necessidade externa do corpo. A ilegibilidade dos signos do sexo ou seu esvaziamento, presença e ausência ao mesmo tempo, é só uma parcela da crise contemporânea de identidades.

O regime do travestido torna-se a base de um comportamento social que se move em busca de identidade e diferença, mas que, no entanto, cai num excesso teatral de ambigüidade. Identidades e diferenças assumem

${ }^{50}$ Em História da Literatura Erótica, Alexandrian faz a seguinte distinção: “A pornografia é a descrição pura e simples dos prazeres carnais; o erotismo é essa mesma descrição revalorizada em função de uma idéia de amor ou vida social. Tudo que é erótico é necessariamente pornográfico, com alguma coisa a mais. É muito mais importante estabelecer a diferença entre o erótico e o obsceno. Neste caso, considera-se que erotismo é tudo o que torna a carne desejável, tudo o que a mostra em seu brilho e em seu desabrochar, tudo o que desperta uma impressão de saúde, de beleza, de jogo deleitável; enquanto a obscenidade rebaixa a carne, associa a ela a sujeira, as doenças, as brincadeiras escatológicas, as palavras imundas. ALEXANDRIAN, 1993, p. 08.

${ }^{51}$ BAUDRILLARD, A transparência do mal, p. 28 
qualidades confusas, difusas, reduzidas. Após liberadas todas as virtualidades do desejo, é imperativo que o sujeito se faça uma interrogação fundamental: "sou um homem ou uma mulher?"52. O caminho da liberação tornou-se, também, o da indeterminação, da insegurança subjetiva.

Depois da transexualização do mundo, é possível encontrar cada vez menos respostas possíveis para a identidade e para a diferença. O conceito de identidade fixa desmoronou com a circulação dos signos e da multiplicação das formas de gozo. A crise e o excesso fizeram das identidades espaços subjetivos cada vez mais provisórios, variáveis e fragmentados. Os sujeitos permanecem perdidos, alternando-se em centros de identidade cada vez mais confusos e fundidos, não identificando outra alternativa que não seja a de seguir o fluxo contínuo. Ou, na pior das hipóteses, de estancar o jorro.

O narrador de $A$ céu aberto opta pela interrupção ao extinguir um corpo duplo, estranho, sem nome. A ação é motivada mais pela falta de compreensão de sua natureza que por uma razão plausível para a gana assassina, pois o desejo era eclipsar o corpo para escurecer a loucura. $\mathrm{O}$ exílio em terra estrangeira, ao final da narrativa, longe de sinalizar abandono ou renúncia, reitera uma imagem que continuará a se repetir: a de um tatear cego sobre um corpo no escuro. O da escrita.

\footnotetext{
${ }^{52}$ BAUDRILLARD, A transparência do mal, p. 29-31.
}

\section{REFERENCIAS}

ABREU, Caio Fernando. Morangos mofados. 9. ed. São Paulo: Companhia das Letras, 1995.

ALEXANDRIAN. História da literatura erótica. Tradução de Ana Maria Scherer e José Laurênio de Mello. Rio de Janeiro: Rocco, 1993.

CHEVALIER, Jean; GHEERBRANT, Alain. Dicionário de símbolos. Tradução de Vera da Costa e Silva [et. al.] 16. ed. Rio de Janeiro: José Olympio, 2001.

BAUDRILLARD, Jean. A ilusão vital. Tradução de Luciano Trigo. Rio de Janeiro: Civilização Brasileira, 2001.

. A transparência do mal: ensaio sobre fenômenos extremos. Tradução de Estela dos Santos Abreu. 9. ed. Campinas: Papirus, 1990.

A troca impossível. Tradução de Cristina Lacerda e Teresa Dias Carneiro da Cunha. Rio de Janeiro: Nova Fronteira, 2002. Difel, 2007.

Senhas. Tradução de Maria Helena Kühner. 2. ed. Rio de Janeiro:

BRUNEL, Pierre (org.). Dicionário de mitos literários. Tradução de Carlos Süssekind [et. al.] 3. ed. Rio de Janeiro: José Olympio, 2000.

COMPAGNON, Antoine. Os cinco paradoxos da modernidade. Tradução de Cleonice P. B. Mourão, Consuelo F. Santiado e Eunice D. Galéry. Belo Horizonte: UFMG, 1999

HILST, Hilda. O caderno rosa de Lory Lamb. 2. ed. São Paulo: Globo, 2005. NOLL, João Gilberto. A céu aberto. São Paulo: Companhia das Letras, 1996. ROSSET, Clément. O real e seu duplo: ensaio sobre a ilusão. Tradução de José Thomaz Brum. Porto Alegre: L\&PM, 1988. 